\title{
Literature inside the Tree: Teaching The Tempest in The Bahamas Department of Correctional Services Facility at Fox Hill
}

\author{
Philip Smith \\ English Studies \\ University of The Bahamas
}

\begin{abstract}
This paper seeks to assess the utility of a Shakespeare Behind Bars programme at The Bahamas Department of Correctional Services Facility at Fox Hill. It argues that, consistent with Kidd and Castano's (2013) findings, students engaged in literary analysis practice "Theory of Mind" and cultivate the means to narrate their own history. Students, we found, refracted their life experience to the play, reading the text in terms of social ostracism, the influences of their life course, imprisonment, and reform. They tended to relate most closely to those characters whom they saw as having learned from incarceration and who were committed to a new life course. Their insights provided a perspective on the play to which we instructors would not otherwise have had access.
\end{abstract}

\section{Introduction}

In May 2018, Dr. Craig Smith and I, faculty members at University of The Bahamas, launched the first Shakespeare Behind Bars programme at the Bahamas Department of Correctional Services Facility at Fox Hill (henceforth Fox Hill), formerly known as Her Majesty's Prison. The course ran for six weeks concurrent with the University's summer one session. Each week we made two visits to the prison, on Tuesdays and Thursdays from 1 p.m. to 3 p.m., for a total of 24 contact hours. We also set reading assignments to be completed outside of class. Our class began with 18 students - 14 males and four females - aged 23 to 53, all of whom were in medium security serving sentences of one to three years. ${ }^{1}$ Class size

${ }^{1}$ The facility has separate blocks for men and women. The educational programmes are one of the rare times when the two prison populations mix. tended to fluctuate throughout the course; in the third week, for example, we lost six students as a result of a timetable clash with other educational programmes.

The students had been selected by the prison's education director, Ms. Andrea Sweeting, based on our recommendation that participants possess a reasonable level of literacy. The majority of our students had previously been involved in a film-making course. All students had attended high school although not all had graduated. One had experience of higher education. When we asked students what previous experience they had of Shakespeare, four reported having watched films of Shakespeare's plays, generally Romeo and Juliet and Macbeth, in school. The others reported minimal experience (one wrote: "nothing" and another "he was a famous writer"). Our primary text for the course was the Signet

(c) P. Smith, 2018. https://orcid.org/0000-0001-7781-4350

(C) International Journal of Bahamian Studies, 2018. https://doi.org/10.15362/ijbs.v24i0.306 
version of The Tempest - an edition which comes with a detailed introduction, a representative sample of critical essays and a brief history of the text in performance. We chose The Tempest because, first, it is a play which we felt touches upon themes of incarceration and second, because it has inspired a great deal of postcolonial writing of relevance to The Bahamas. None of the students had studied the play previously.

The course followed a structure similar to one we might teach at the University albeit with greater restrictions on the material we were able to bring to class (for example, we required special permission to bring in a laptop) and the students' access to resources for assignments between sessions. The low number of contact hours as well as various administrative and logistical processes attendant to the launch of a new course, meant that the programme did not carry university credit. We did, however, present students with a certificate at the end of the course for them to use in future parole hearings. We spent the first three weeks reading through the play, pausing for analysis and discussion. During this time we introduced, where appropriate, key concepts in reading Shakespeare, such as the difference between verse and prose and forms of address in Early Modern English. In the final three weeks we discussed the play's production history, watched excerpts from performances, considered critical readings and looked at responses to The Tempest by Caribbean writers. The students completed two assignments: a creative writing exercise in week three in which they wrote a pre-history of the play from the perspective of a character of their choice and a final essay at the end of the course in which they responded to their choice of a range of critical readings.

We chose Shakespeare knowing that his presence in curricula may be controversial.
Shakespeare has a long history in The Bahamas which coloured perceptions of the programme in the larger community and informed the ways in which we presented the text to our students. When Dr. Smith and I appeared on The Bahamas' Guardian radio to discuss our work in the prison, for example, one listener sent a text message to the host describing our work as "white propaganda." Another applauded the teaching of literature in prison but asked why we were not teaching Caribbean literature.

In part, these responses were informed by the use of Shakespeare as a propaganda tool throughout the British Caribbean during the 19th and early-to-mid-20th centuries. The Royal Reader textbooks, which featured Shakespeare extracts, were used in elite schools and visits from touring companies travelling between America and Europe frequently made stops in The Bahamas and Jamaica. Knowledge of Shakespeare served, as elsewhere in the British Empire, as a signifier of a private education (perhaps even an education abroad) and a privileged status within the colonial hierarchy (Smith, 2017a; Smith, 2017b; Folger Shakespeare Library, 2015).

Shakespeare's works were also used as a means by which the occupiers sought to curb anti-colonial resistance and cement their relationship with their collaborators (Bhatia, 1998). The Tempest, and Caliban in particular, has, of course, also been appropriated by Caribbean writers and translated into an anti-colonial text. Examples of such works include Agard's Prospero Caliban Cricket (1994), Césaire's Une Tempête (1975), Nunez's Prospero's Daughter (2006), and Hopkinson's Shift (2012). The Tempest was also the first play performed at the annual Shakespeare in Paradise Festival in 2009. 
When I entered the prison facility I was not sure what to expect. Dr. Smith and I were not sure how much material we could cover in each class or how the students would respond to Shakespeare's language. Would they be frustrated, I wondered? Indifferent? I was also unsure how the students would respond to the readings we planned to present. Various critics and performers have discovered in The Tempest themes of incarceration, power, violence and exploitation, all of which (I assumed) would prove eminently relevant to our student's own lives. But would it be, I wondered, presumptuous or even insulting of us to present these themes and expect them to respond? In presenting Shakespeare to these students were we, as the listener to the radio station suggested, forcing a disempowered population to understand their own lives through artifacts from a (neo)colonial culture?

During our visits to Fox Hill, we learned a great deal not only about the experience of incarceration as understood by those who live it, but about the play itself. The students created meanings from the text which neither of us had previously encountered. When the students read and analysed The Tempest, they engaged in a process which required them to imagine the motivations and emotions of another, imbuing the characters with fragments of their own life experience in ways we had not anticipated. Students, we found, tended to understand characters' behaviours as a result of circumstances. They were sympathetic to Caliban, whom they read as a victim of a poor upbringing. They saw themselves in Ariel and (to a lesser extent) Prosperocharacters whom they read as being capable of emerging from incarceration with more emotional maturity and a clearer sense of purpose than when they arrived. Our experience working with students at Fox
Hill rhymes with earlier studies concerning the positive effects which literary analysis can have on incarcerated populations. It also affirms the oft-made assertion that literature and theatre, and Shakespeare in particular, are capable of producing different meanings from different populations - that whenever a reader and a text meet, a new meaning is born.

\section{Shakespeare in Prison: Current Debates}

Our involvement in the prison is the latest fold in an ongoing relationship between the University and The Bahamas Department of Correctional Services. In 2016, researchers from the University surveyed inmates at Fox Hill. The results informed many chapters in the book Violence in The Bahamas (2016) and were presented in 2018 at a symposium at University of The Bahamas titled Our Prisoners attended by members of the Ministry of National Security and representatives of the Inter-American Development Bank. The proceedings of the symposium are to be published by IDB in 2019.

Many of the findings which emerged from the survey informed our decision to launch the Shakespeare prison programme, most significant among them being the clear relationship which has been established between low educational achievement and criminality. As Symonette (2016), Fielding (2016), and Johnson (2016) have shown, prisoners in The Bahamas tend to have a lower level of educational attainment than the rest of the population. This may be the result of growing up in unstable and, in many cases, violent households-factors which are highly disruptive to learning (Johnson, 2016). As a result of their low level of education, many struggle to achieve an income through legal means which is commensurate with their needs (Dames \& 
Smith, 2017).

In their introduction to the forthcoming joint-publication with IDB, Sutton, VeyratPontet and Fielding (forthcoming) advocate for sentencing which includes an educational component, arguing that providing inmates with greater access to education may be a key means to raise their earning potential and thus curb recidivism. The purpose of our Shakespeare programme, then, was twofold: in the short term we sought to provide an educational experience to, and to empower, an under-served community by giving incarcerated students an experience of higher education. In the long-term we sought to take a first step towards bringing adult education and/or for-credit university courses into the prison.

In addition to enhancing the educational prospects of prisoners, we also have reason to believe that Shakespeare programmes in prison have more immediate benefits. Anecdotal and empirical evidence from programmes outside of The Bahamas suggests that Shakespeare in prison programmes provide participants with a sense of purpose and accomplishment, lower the frequency of disciplinary instances for participants and the prison population as a whole, and lower the likelihood of recidivism after release.

Shakespeare programmes in prison, either built around performance or literary study, have existed for more than two decades in the United States and Europe. Prison performances have an even longer history, dating to the American Civil War if not earlier (Scott-Douglass, 2007). Shakespeare programmes have generated, most famously, Philomath Film's documentary Shakespeare Behind Bars (2005), which follows a performance of The Tempest staged by prisoners in Kentucky in 2005, and Bates' memoire, Shakespeare Saved My Life
(2013), concerning her work teaching Shakespeare to maximum security prisoners in Indiana State Prison.

There exists a growing body of evidence to suggest that studying Shakespeare benefits incarcerated communities. Shailor (2013) asserts that students enrolled in his programme at Racine Correctional Institution received ten times fewer disciplinary reports than those who were not enrolled. In addition, the introduction of the programme appears to have had a positive impact on the prison population as a whole. The disciplinary report factor for the entire prison population dropped every year the programme was in operation from 2.25 per prisoner in 2004 to 1.54 per prisoner in 2008. In 2009, after the cancellation of the Shakespeare programme, the number of disciplinary reports rose again to 2.85 . Wilcox (2012), artistic director of Prison Performing Arts, reports that recidivism rates for those involved in the theatre programme at prisons in Missouri are one third of their peers who did not participate in the programme.

The Shakespeare Behind Bars programme in Luther Luckett Correctional Complex, Kentucky, similarly reports a recidivism rate of just $6.1 \%$ for participants-below the state average of $29.5 \%$ and far below the national average of $67 \%$ (Shakespeare Behind Bars, 2018).

We should, of course, be hesitant to place too much trust in such findings. If participation in Shakespeare or similar programmes is a reward for good behaviour, if participants are self-selecting, or if those enrolled were chosen because they have a higher level of educational attainment than their peers, for example, then the selection of individuals involved may not be representative of the prison population as a whole. It is also difficult to factor for other 
events at the prison, independent of the Shakespeare programme, which may impact discipline. Such data are, however, supported by self-reports from participants. One inmate enrolled in Dr. Wall's London Shakespeare Workout programme reports, "you get dumber and dumber by the day [in prison]. This [Shakespeare programme] woke us up - it gave us a reason to wake up as a team. It fills your mind with purpose instead of frustration and dread" (Barber, 2018. para. 25). As Wilcox (2012) asserts:

Many men and women are in prison because they have limited problemsolving skills. Their lives have been chaotic, and they have not been able to create a structure for that chaos. Literature, with its use of language and with its study of character and circumstance, helps them see and articulate the process of cause and effect in human lives, sometimes their own.

One finds similar reports elsewhere. Judge Paul Perachi, whose Shakespeare in the Courts programme requires juvenile offenders to participate in Shakespeare programmes as an alternative to other punitive measures, asserts that there is an "inexplicable magic" to performing Shakespeare (Scott-Douglass, 2007, p. 4).

It is far too soon for us to determine whether our Shakespeare Behind Bars programme has had a positive effect on rates of recidivism, and data on disciplinary actions are, unfortunately, not available. We can, however, document self-reports among prisoners concerning the extent to which studying The Tempest facilitated a process of, as Wilcox (2012) argues, recognizing and describing the emotions and motivations of others and arranging one's life-experience into a narrative. The ways in which the students engaged with the text also provides insights into their beliefs and attitudes concerning incarceration and brings new meanings to the text.

\section{Shakespeare at Fox Hill}

Dr. Smith and I both entered the prison with certain expectations as to how our students would respond to The Tempest. Neither of us had any previous experience working in prisons or with incarcerated or formerlyincarcerated students. We both knew from the prison study that the typical prisoner at Fox Hill is an unmarried male between 18 and 30 years old who, prior to incarceration, was unemployed or worked in a low-wage job (see Minnis, Symonette, Stevenson, Pintard-Newry, \& Gibson, 2016). Our expectations, inevitably, had also been shaped by popular representations of prison life and so we anticipated that prison culture would demand our students perform certain models of hype-rmasculine or otherwise "tough" behaviour which might shape their approach to the text. I had expected, for example, for the students to respond positively to more performatively masculine characters such as Caliban and to either resist discussions concerning or be dismissive of subservient or feminine characters such as Ariel or Miranda.

I was not alone in my assumptions. In her novel Hag Seed (2016), Margaret Atwood describes a fictional staging of The Tempest in a prison in which the characters' responses to the play follow somewhat unnuanced models of class and masculinity and a refusal to engage with characters whom they perceive as feminine. The programme's director, Felix, sees his students as "various Calibans, scowling muscular: earthy, potentially violent" (2016, p. 85). The prisoners see themselves in much the same way: 15 of Felix's students volunteer for the role of Caliban in their performance, compared to eight for Ferdinand, five for Antonio, two for each of 
Stephano and Trinculo, and zero for Alonso or Sebastian (2016, p. 119). Atwood suggests that the prisoners identify with Caliban because they read him as a marginalized figure who resists subjugation. As Vaughan and Vaughan argue, Caliban is often read as an "emblem of oppressed natives. $[\mathrm{He}]$ stands for countless victims of European imperialism and colonization" (1991, p. 145). Indeed, the prisoners in Atwood's novel are all eager to claim Caliban as one of their own:

"Caliban should be First Nations," says

Red Coyote. "It's obvious. He got his land stole."

"No way," says PPod. "He's African. Where's Algiers anyway? North Africa, right? That's where is mother came from. Look on the map pox brain." (2016, p. 152)

Ariel (who is, of course, also native to the island) finds much less traction than Caliban; the first time Felix mentions that the play contains a fairy the students react with hostility. Once they begin reading they see Ariel as far too servile; he is a "good servant" to Caliban's "bad servant" (2016, p. 106). During his first meeting with his students, Felix concludes that "no one wants either of these parts: not the Ariel, not the Miranda" (2016, p. 88). The reason is simple: to play "a fairy" is to appear less masculine (2016, p. 88). Felix asserts that "any man playing [a feminine role] would lose status in a disastrous way. He'd become a butt, a target. Playing a girl, he'd risk being treated as one" (2016, p. 88). Felix eventually persuades them to see Ariel as an alien or superhero and to construct the character through stage effects rather than being played by an actor (2016, pp. 105106). In Hag Seed, then, the fictional students' willingness to engage with the text is limited by the characters with whom they are prepared to empathize. Their perceived need to adhere to certain models of masculinity prevents them from engaging with the texts in other ways.

Our experience at Fox Hill prison was quite different from both my expectations and the hypermasculine world portrayed by Atwood. Early in the programme, we explained that any role in the play could be read by anyone and that the first Miranda was almost certainly played by a boy actor. Our students, unlike those portrayed by Atwood, were generally happy to have the chance to exercise skills they learned in their filmmaking class by reading a part aloud regardless of the character they were playing.

The minority who were reluctant to read did not seem to be reticent because they did not want to read a feminine role, so much as embarrassed to read aloud at all. (While we instructors did not correct a student's pronunciation, other students sometimes did.) There was certainly no sense of status loss when students read for characters of the opposite gender. Even the reading of a male/male Miranda and Ferdinand declaring their love for one another in 3.1 elicited no comment. The one moment of laughter came when the student playing Miranda delivered the line "my husband, then?" (Shakespeare, 2005, 3.1.88, p. 1234) in a tone which suggested disappointment rather than joy. The selection of students, of course, was curated rather than a crosssection of the prison population and their behaviour was no doubt informed by our presence and the circumstances of the course. Nonetheless, we found them to be far more amenable to gender-crossed reading and engagement with feminine characters than Atwood's novel and our preconceptions might suggest. When, in the second week, we asked the students which character they found most sympathetic the first answer we 
received, from a male student, was Miranda because, he argued, she serves as an audience surrogate in the first act-like her, he does not know the circumstances, yet to unfold, which inform the story.

The question of a character's internal state and motivations was at the centre of our first assignment in which students imagined the history of a character of their choice. Nine students participated: four wrote about Caliban, two Antonio, three chose Ariel, and one chose Stephano. One student did express sentiments that resembled those found in Hag Seed. He wrote: "I like Antonio because he wants to be the boss and he will do whatever it takes even if he has to kill his own brother and his little girl." For the most part, however, students' reactions were far more empathetic. Those who chose Caliban, for example, did not see him as a model of resistance, but as a figure of pity and a victim of circumstances. One wrote:

I chose [Caliban] because he seems to be the most misunderstood person in the play so far. And I feel his reasons for being bitter toward Prospero and wanting him killed should be revealed. It kind of relates to society's view on angry young people or those who are charged with violent crimes like myself.

The student identifies with Caliban because he experiences social exclusion. She ties this directly to her own experience as an incarcerated individual. As Pintard-Newry and Parker (2017) report, prisoners in The Bahamas are often concerned as to how they will be regarded after release; many cited fear of rejection by family and peers and the fear of being stigmatized for having been in prison as significant concerns. In her accompanying creative piece the student, like many of her classmates, mentions that Caliban's relationship with Prospero changed after Caliban showed sexual interest in Miranda - that the condition in which we find him at the beginning of the play (as one student phrases it, "reduced to living in a rock") is the result of an informal system of punishment. She felt that Prospero's treatment of Caliban represents a punitive model built upon ostracism and retribution without the possibility of reform or a return to society. Drawing a parallel between Caliban and the post-incarceration experience in The Bahamas, she writes (paraphrasing the motto beneath the prison logo): "the underlying issues should be dealt with in order to begin rehabilitation, reform, and reintegration into the free world."

It is perhaps important to note that, as critics such as Taylor (1989) maintain, when students read Shakespeare or any other literary work the process in which they engage uses similar mechanisms but is distinct from attempts to understand the interior experience of another human being. ${ }^{2}$ This point of clarification is important because there exists a long tradition of reading Shakespeare as able to speak to that which is "essentially human." Such a reading would suggest that Shakespeare's insights into the human condition are so keen that his characters have all of the contradictions, dimensions and complexities of an actual personage rather than a literary construction. This idea proved particularly popular during the 19th century. S. T. Coleridge, for example, claimed in 1836 that he has "a smack of Hamlet" in his personality (as cited in Bate, 1992, p. 161). Such views persist today most famously in

\footnotetext{
2 This theory is somewhat contested. Yachnin and Slights (2009), for example, argue that while arguments concerning "character" are often treated with scepticism by literary scholars, they nonetheless constitute an important part of nonspecialist responses to texts. By rejecting such responses we risk losing important dialogue with students, theatre professionals, and nonspecialist readers.
} 
Bloom's Shakespeare: The Invention of the Human (1999) in which Bloom claims that we owe our modern ideas of interiority to Shakespeare. To offer an example closer to our subject, in Shakespeare Saved My Life, Bates asserts that she "wanted to learn from these convicted killers whether Shakespeare's representation of murder is accurate" (2013, p. 53). These ideas are problematic because, in treating literary invention as a genuine personage, they obscure more than they reveal. Tennenhouse (2010), for example, argues that we tend to be highly selective in which parts of Shakespeare we read, debate, and perform, creating "a construct who speaks the politics of culture in the tradition of [Matthew] Arnold and [T. S.] Eliot" (2010, p. i). As Gary Taylor writes, Shakespeare "gives us back our own values" (1989, p. 411). Whatever we believe about the world or ourselves we tend to find in Shakespeare, not because Shakespeare somehow anticipated the shape our lives would take, but because we create from his words confirmation of our existing beliefs.

This context is key to our understanding of the students' responses to the text. When we tasked our students with creating a history for particular characters, they did not discover a character created by Shakespeare, but created one from their own experience in dialogue with evidence they found on the page. As we emphasized throughout the course, the brevity of Shakespeare's stage directions and, more importantly, the "gaps" left in the text mean that we can imagine any number of versions of each of the characters, none of which are more "correct" than any other. The implications of this are two-fold. First, this process may make the magic described by Judge Paul Perachi a little more explicable. As Kidd and Castano (2013) demonstrate, reading literary fiction (as distinct from non-fiction and popular fiction) enhances one's Theory of Mind (ToM) - the ability to understand the emotions of others. They assert:

Our contention is that literary fiction, which we consider to be both writerly and polyphonic, uniquely engages the psychological processes needed to gain access to characters' subjective experiences. Just as in real life, the worlds of literary fiction are replete with complicated individuals whose inner lives are rarely easily discerned but warrant exploration. The worlds of fiction, though, pose fewer risks than the real world, and they present opportunities to consider the experiences of others without facing the potentially threatening consequences of that engagement. More critically, whereas many of our mundane social experiences may be scripted by convention and informed by stereotypes, those presented in literary fiction often disrupt our expectations. Readers of literary fiction must draw on more flexible interpretive resources to infer the feelings and thoughts of characters. That is, they must engage ToM processes (2013, p. 378).

Engaging in literary analysis or preparing for a performance, then, provides a safe opportunity to simulate the process of exploring the inner life of another. Indeed, because the act of interpreting literature occurs at a pace which the reader can control, literary analysis may provide a more effective path to developing ToM than human interactions alone because it simulates the process of engaging with another without the immediacy or pressure of live dialogue. The ability to recognize the logic that informs the behaviour of others may be a particularly useful skill for those with a history of violence as the inability to apply the emotional aspects of ToM has 
been linked to antisocial behaviour (Shamay-Tsoory, Aharon-Peretz, \& Levkovitz, 2010). The positive effects of reading literature in prison, then, may account for the drop in disciplinary action during incarceration as well as the reduced rates of recidivism after release. The process of interpreting the actions of characters may explain the positive behaviours observed in Shakespeare prison programmes. The act of interpretation-of the reader completing the text as it werealso brings forth themes and observations which might elude another reader. When the student mentioned above describes the relationship between Prospero and Caliban, she constructs a non-functional model of incarceration built from her own experience and anxieties, both engaging her ToM and describing a world to which we on the outside have no access.

This process of interpretation continued into other activities. When we discussed with the students how they would cast the play, for example, all of the groups, independent to one another, chose to cast Caliban as black and Prospero and Miranda as white. In the ensuing discussion we considered the oft-observed analogy of Prospero as colonizer, Caliban as colonized and Ariel as collaborator. Despite their casting choices, the students were reluctant to, as they saw it, reduce these potentially complex characters to historical allegory. One group pointed to the text as justification-Prospero and Miranda are from Milan and Caliban's mother was from Algiers. All agreed, however, that the term "slave" brought to mind images of the transatlantic slave trade and whenever they pictured Caliban they imagined him as black. It is perhaps also relevant that the perception persists in The Bahamas (not without justification) that white and lighter-skinned Bahamians generally have greater wealth and social capital than their darker-skinned countrymen (Bethell-Bennett, 2016). When we discussed this, the students agreed that while they could imagine a white Caliban in theory, they would choose a reading of the play which more closely resembled their own experience of racial power dynamics.

Other students read The Tempest as a meditation on the ways in which one's circumstances can affect the course of one's life. In the first assignment, one writes that she chose Caliban "because I felt as though he was treated poorly because of something his mother did in the past. He was brought up very badly." Her narrative of Caliban's history focused on his status as the child of a single parent (Sycorax was put on the island while pregnant and Prospero calls Caliban a "bastard" [Shakespeare, 2005, 5.1.276, p. 1242]). In a creative piece later in the course, another student wrote:

Young, black, like Caliban

Came up from da bottoms

Sycorax, always absent

Like modern age mommas

It is significant that the majority of individuals incarcerated at Fox Hill grew up in single-parent households, with the largest percentage being raised by a single mother (Minnis et al., 2016). The students' reading of Caliban is consistent with Stevenson's claim that prisoners at Fox Hill "organize their thinking about crime causality in terms that suggest an acute awareness of economic disparities in society" (2016, p. 227). In other words, they recognize that their own life course is the result of social and economic, rather than personal, factorsthat they are born into a country with a high cost of living and a large gap between rich and poor, where some individuals feel that criminality is the only means by which they can achieve their desired level of income. Those households supported by a single 
parent, Minnis et al.'s work suggests, are far more likely to grow up in a low-income and potentially unstable environment. Thus, they are at a greater risk of criminal behaviour later in life. The student recognizes in Caliban many of the factors which inform the lives of the incarceratedhe sees his actions as the result of his upbringing. The students' responses, then, seem to support Wilcox's assertion, quoted above, that working with Shakespeare allows students the opportunity to interpret characters' actions as part of a network of cause and effect. This interpretation, one might speculate, can in turn inform their thinking about their own life course.

The student who chose Stephano also offered an extended reading of the ways social influences can lead to criminal behaviour and incarceration. He imagined Stephano as the child of an aristocratic family who did well in school but fell from grace. He writes, as Stephano: "Life was good, but as I became an adult I developed a passion for gambling, booze, and fast women." In his back-story for the character, Stephano gets into debt from gambling and appeals to his family for help. Rather than support, however, he is rejected: "they beat me and knocked me out. When I awoke I was shackled on a slave ship to Italy." While the student is keenly aware of the ease with which an individual can be drawn into criminal activities and experience ostracism as a result, he added in his reflection that he did not model Stephano after himself, but others he has observed in prison, suggesting a movement back and forth between literary analysis and the application of ToM in his interactions with others.

While the fictional students in Atwood's novel were drawn primarily to Caliban, in our class Ariel attracted an equal degree of interest and discussion. While the students tended to identify Caliban as a figure of pity whose circumstances have informed his life course, few of them saw themselves in the character, preferring to see him as a type they have encountered. This corresponds with Symonette's finding that $79.9 \%$ of those incarcerated at Fox Hill did not see themselves as criminals (2016, p. 247). It was Ariel, more than any other character, with whom the students seemed most to identify. Our students were particularly interested in the dialogue between Prospero and Ariel in 1.1 where they discuss the bargain over Ariel's freedom. Whenever we discussed Ariel's role in the play, the fact that Ariel was trapped in a tree and now seeks his liberty was cited frequently as motivation for the character. On more than one occasion students speculated that Ariel may be masking his true emotions for fear that his deal with Prospero might sour. In his reflection one student wrote, "Ariel was desperate to be freed and did whatever was necessary to gain his freedom." Another wrote, "I chose Ariel because of the current situation ... I've been tempted, depressed, and enraged to the point of tears. I can't wait to get out of this tree." For many of the students, then, Ariel represents a model of prison life which resembles their own-a character who is prepared to suffer hardship to achieve freedom. This reading of Ariel resonated so strongly that many students (both male and female) reported that they saw themselves in Ariel. One student wrote that Ariel is

a fighter. She will do anything to gain her liberty back. She reminds me of myself. She's determined to get the job done regardless of what kind and to what extreme. She'll prove herself worthy. But she's smart in her own ways.

We see here a clear example of a student using a literary character to organize her own narrative. 
In week five of the course we read scenes from a translation of Césaire's Une Tempête (1975) which complicated many students' previous reading of the play. In one scene, Césaire's version of Ariel and Caliban discuss their respective philosophies of resistance: Ariel believes that he can change Prospero and win his freedom, whereas Caliban believes that freedom must be taken by force. The students tended to find Caliban more persuasive than Ariel. However, one student argued that while the violent resistance espoused by Caliban might be appropriate in a total institution of the slave plantation, in prison - another total institution-someone who adopted Ariel's philosophy of cooperation would pass parole whereas Caliban's combative approach would lead to a stay in maximum security. In practice, he asserted, they were all Ariels.

The theme of earning one's freedom and doing one's duty returned repeatedly in our readings of the text. It seemed obvious to many of the students, for example, that Prospero persisted in his exile for the sake of Miranda. As one student asserted, he had to "do right by his little girl." Students related Prospero's experience to the pressures which incarceration places on their relationship with their own children. For many, Prospero's imprisonment on the island was a learning experience from which he might emerge reformed. After we finished reading the play we invited the students to speculate what might come next for the characters. One group imagined that Prospero would be a better ruler than he was previously - that his time imprisoned on the island will have improved his outlook and taught him practices in statesmanship that he had previously seen no need to cultivate. Such readings suggest that our students see their incarceration as unpleasant and painful (akin to being trapped in a tree) but look forward to their release as an opportunity to set out on a new life course.

\section{Conclusions}

There is far more work to be done concerning the effects of the Shakespeare course on participants. To do so, one would need to measure instances of disciplinary reports before and after participation in the course and track the rates of recidivism of participants after release. At present we do not have data to measure these outcomes. If, however, we understand the development of ToM through literature as, to borrow Kidd and Castano's phrase "fill[ing] in the gaps" (2013, p. 377) by projecting meaning onto a literary construct then we find abundant evidence of, as Wilcox (2012) asserts, students creating narratives of cause and effect in character's lives and, in doing so, reflecting upon and building a narrative of their own experience. Students generally recognized the experiences of others in Caliban; they read Caliban as an economically disadvantaged black man who had grown up in a single-parent home, had been failed by social systems and was suffering from social ostracism and isolation as a result of a single bad decision. Few of them saw Caliban's experience as a direct reflection of their own, however. Instead, they tended to identify with Ariel and Prospero: two characters who have been imprisoned but are striving to earn their freedom and build a better life upon release.

Bringing Shakespeare into prison has potential benefits for both prisoners and for Shakespeare. Evidence suggests that those who enrol in such courses benefit from the development of ToM which results from literary interpretation. This may improve behaviour during incarceration and lower the likelihood of recidivism after release. These courses also open new forms of interpretation. If there has been a theme in Shakespeare during the 20th century, it is 
that performance is enriched by a multitude of perspectives. As, to name a few, Kennedy (1993), Brandon (2010), and Loomba (2002) have shown, approaches to Shakespeare around the world have been transformed by performances which have emerged from India, Japan, China and Africa. When incarcerated students at Fox Hill read The Tempest, they read it through the lens of both incarceration and the racial and economic divisions still prevalent in The Bahamas. Over the course of six weeks the students, with our prompting, developed a reading of the play which is unique to their situation and provides an understanding of each of the characters within contemporary social frameworks. Their reading was nuanced, persuasive and eminently relevant to The Bahamas today. In this sense, the benefits of the programme were reciprocalnot only did the students have the opportunity to develop their ToM, but we instructors learned to see The Tempest anew.

\section{References}

Agard, J. (1994). Prospero Caliban cricket. Massachusetts Review, 35, 546-548. Available at https://www.jstor.org/stable/25090559

Atwood, M. (2016). Hag seed. London: Hogarth

Barber, L. (2018, February 2). Shakespeare workshops in prisons are like sunshine after rain for inmates. INews. Retrieved from https://inews.co.uk/news/uk/shakespeareworkshops-prison/

Bate, J. (1992). The romantics on Shakespeare. London: Penguin Classics.

Bates, L. (2013). Shakespeare saved my life. Chicago: Sourcebooks.

Bethell-Bennett, I. (2016). In the shadows of violence and trauma: The state, postslavery and neoliberal racial constructs. In W. J. Fielding, V. C. F. Ballance, \& I. G. Strachan (Eds.), Violence in The Bahamas (pp. 1-21). Nassau: University of The Bahamas/Media Enterprises.

Bhatia, N. (1998). Shakespeare and the Codes of Empire in India. Alif: Journal of Comparative Poetics, 18, 96-126. https://doi.org/10.3167/cs.2011.230306
Bloom, H. (1999). Shakespeare: The invention of the human. New York: Riverhead Books.

Brandon, J. (2010) Other Shakespeares in Asia: An overview. In P. Trivedi \& R. Miami (Eds.), Re-playing Shakespeare in Asia (pp. 21-40). New York: Taylor \& Francis.

Césaire, A. (1975). Une tempête. New York: French \& European Publications.

Dames, A., \& Smith, P. (2017, October 4). Thieves: Who are they? Paper presented at Our Prisoners: A Symposium, University of The Bahamas.

Fielding, W. J. (2016). Violence in the life of an inmate prior to conviction and its association with crimes against persons. In W. J. Fielding, V. C. F. Ballance, \& I. G. Strachan (Eds.), Violence in The Bahamas (pp. 205-220). Nassau: University of The Bahamas/Media Enterprises.

Folger Shakespeare Library. (2015, November 4). Shakespeare in the Caribbean [audio podcast]. Retrieved from http://www.folger.edu/shakespeareunlimited/caribbean

Hopkinson, N. (2012). Shift: Report from Planet Midnight. Oakland, CA: PM Press. 
Johnson, P. (2016). Violence in schools. In W. J. Fielding, V. C. F. Ballance, \& I. G. Strachan (Eds.), Violence in The Bahamas (pp. 113-134). Nassau: University of The Bahamas/Media Enterprises.

Kennedy, D. (1993). Introduction:

Shakespeare without his language. In D. Kennedy (Ed.), Foreign Shakespeare: Contemporary performance (pp. 1-17). Cambridge: Cambridge University Press.

Kidd, D. C., \& Castano, E. (2013). Reading literary fiction improves theory of mind. Science, 342 (6156), 377-380. https://doi.org/10.1126/science.1239918

Loomba, A. (2002). Shakespeare, race, and colonialism. Oxford: Oxford University Press.

Minnis, J., Symonette, E., Stevenson, M., Pintard-Newry, Y., \& Gibson, T. (2016). Who is in Prison? In W. Fielding, V. Ballance, \& I. G. Strachan (Eds.), Violence in The Bahamas (pp. 181-204). Nassau: University of The Bahamas/Media Enterprises.

Nunez, E. (2006). Prospero's daughter. New York: Akashic Books.

Philomath Film. (2005). Shakespeare behind bars. Retrieved from https://www.shakespearebehindbars.org/do cumentary/

Pintard-Newry, Y., \& Parker, Q. (2017, October 4). Family lives of inmates. Paper presented at Our Prisoners: A symposium, University of The Bahamas.

Scott-Douglass, A. (2007). Shakespeare inside: The Bard behind bars. London and New York: Continuum.

Shakespeare Behind Bars. (2018). Kentucky Department of Corrections, Luther Luckett Correctional Complex - LaGrange, KY. Retrieved from https://www.shakespearebehindbars.org/pr ogrammes/kentucky/llcc/

Shakespeare, W. (2005). The Oxford Shakespeare: The complete works. Oxford: Oxford University Press.

Shamay-Tsoory, H. H., Aharon-Peretz J., \& Levkovitz, Y. (2010). The role of the orbitofrontal cortex in affective theory of mind deficits in criminal offenders with psychopathic tendencies. Cortex, 46(5), 668-77.

https://doi.org/10.1016/j.cortex.2009.04.00 8

Smith, P. (2017a). "Upon this blasted heath": Macbeth before and after the hurricane. The International Journal of Bahamian Studies, 23, 40-48. http://doi.org/10.15362/ijbs.v23i0.279

Smith, P. (2017b). Margaret Atwood's Tempests: Critiques of Shakespearean Essentialism in Bodily Harm and HagSeed. Margaret Atwood Studies Journal, 11. Available at https://atwoodsociety.org/volume-11-tableof-contents/

Stevenson, M. (2016). I too grew up poor. In W. J. Fielding, V. C. F. Ballance, \& I. G. Strachan (Eds.), Violence in The Bahamas (pp. 221-237). Nassau: University of The Bahamas/Media Enterprises.

Symonette, E. (2016). Inmate perceptions of their re-entry into Bahamian society. In W. J. Fielding, V. C. F. Ballance, \& I. G. Strachan (Eds.), Violence in The Bahamas (pp. 239-250). Nassau: University of The Bahamas/Media Enterprises.

Taylor, G. (1989). Reinventing Shakespeare: A cultural history from the Restoration to the present. London: Widenfeld \& Nicholson.

Tennenhouse, L. (2010). Power on display: The politics of Shakespeare's genres. New York: Routledge. 
Vaughan, A. T., \& Vaughan, V. M. (1991). Shakespeare's Caliban. Cambridge: Cambridge University Press.

Wilcox, A. (2012, December 18). Prison theater transforms inmates. New York Times. Retrieved from https://www.nytimes.com/roomfordebate/2 012/12/18/prison-could-beproductive/prison-theater-transformsinmates

Yachnin, P. E., \& Slights, J. (2009). Shakespeare and character: Theory, history, performance, and theatrical persons. Basingstoke, England: Palgrave Macmillan. 